\title{
EHMTI-0040. Headaches after traumatic spinal cord injury
}

\author{
L Sabre $^{1 *}$, M Rugo $^{2}$, J Kõrv ${ }^{1}$, M Braschinsky ${ }^{1}$ \\ From 4th European Headache and Migraine Trust International Congress: EHMTIC 2014 \\ Copenhagen, Denmark. 18-21 September 2014
}

\section{Background}

Patients with traumatic spinal cord injury (TSCI) often suffer from different types of pain. However, headaches (HA) after TSCI have not been studied specifically.

\section{Aim}

To examine the HAs among patients with TSCI.

\section{Methods}

The cross-sectional study included individuals with TSCI from 1997 to 2011 who were interviewed via telephone. The interview based on a specifically designed questionnaire.

\section{Results}

There were 9 women and 64 men (mean age $37.1 \pm$ 10.6 years). The most frequently mentioned pain was HA (71\%), followed by back pain (60\%) and pain in neck (44\%). HAs were more frequent after the trauma compared with the HAs before TSCI $(\mathrm{p}=0.01)$. The HAs that arose after TSCI were not related to the concomitant brain injury $(\mathrm{p}=0.80)$. The occurrence of HA did not depend on the severity nor the level of the TSCI.

The most frequently reported HA located in the occipital, was pulsating and lasted from 1 to 3 hours. The maximal intensity of the pain was $6.9 \pm 2.0$ according to the Numeric Rating Scale.

Due to the HA $85 \%$ of the patients were not seen by any physician and their HA was not diagnosed.

\section{Conclusions}

This is the first study that shows that HA is the most prevalent pain after TSCI. Despite this, the majority of patients are never consulted, diagnosed or appropriately

${ }^{1}$ Depratment of Neurology and Neurosurgery, University of Tartu, Tartu, Estonia

Full list of author information is available at the end of the article managed due to their HA. This indicates that further studies are needed to provide evidence regarding the causes of HA and their impact on quality of life.

No conflict of interest.

\section{Authors' details}

${ }^{1}$ Depratment of Neurology and Neurosurgery, University of Tartu, Tartu, Estonia. ${ }^{2}$ Faculty of Medicine, University of Tartu, Tartu, Estonia.

Published: 18 September 2014

doi:10.1186/1129-2377-15-S1-B30

Cite this article as: Sabre et al:: EHMTI-0040. Headaches after traumatic spinal cord injury. The Journal of Headache and Pain 2014 15(Suppl 1):B30.

\section{SpringerOpen $^{\odot}$}

(C) 2014 Sabre et al; licensee Springer. This is an Open Access article distributed under the terms of the Creative Commons Attribution License (http://creativecommons.org/licenses/by/2.0), which permits unrestricted use, distribution, and reproduction in any medium, provided the original work is properly cited.
Submit your manuscript to a SpringerOpen ${ }^{\circ}$ journal and benefit from:

- Convenient online submission

- Rigorous peer review

- Immediate publication on acceptance

- Open access: articles freely available online

- High visibility within the field

Retaining the copyright to your article

Submit your next manuscript at $>$ springeropen.com 